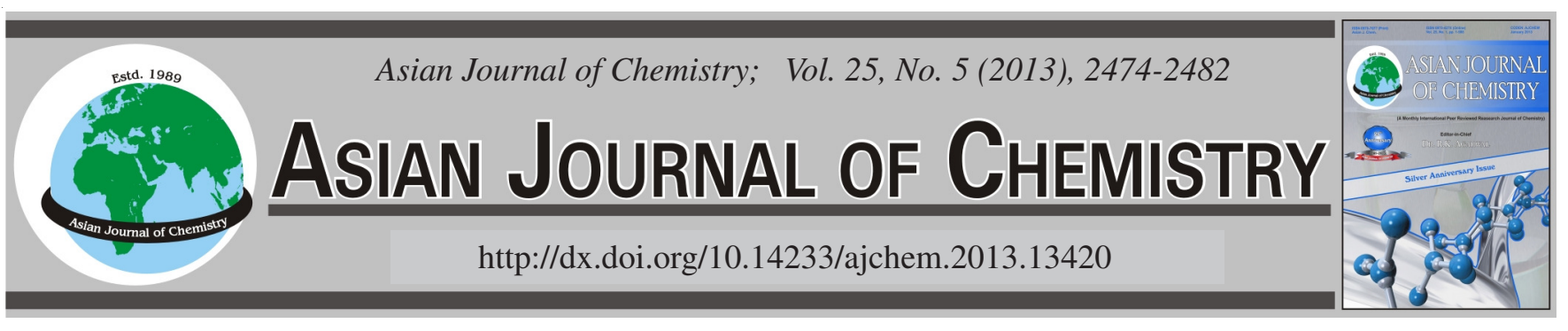

\title{
Removal of Arsenic from Aqueous Solutions Using Zirconium Oxyhydrate Embedded $\mathrm{Fe}_{3} \mathrm{O}_{4}$ Nanoparticle
}

\begin{abstract}
Shaolin Wu ${ }^{1,2, *}$, Wentao Hu ${ }^{1,2}$ and Ming MA ${ }^{1,2}$
${ }^{1}$ Key Laboratory of Jiangxi Province for Ecological Diagnosis-Remediation and Pollution Control, Nanchang 330063, P.R. China

${ }^{2}$ School of Environmental and Chemical Engineering, Nanchang Hangkong University, Nanchang 330063, P.R. China

*Corresponding author: Fax: +86 791 395373; Tel: +86 791 3953372; E-mail: hupeng_521@yahoo.com.cn

A new type of magnetic nanoparticle $\mathrm{Fe}_{3} \mathrm{O}_{4} @ \mathrm{ZrO}(\mathrm{OH})_{2}$ was prepared in $\mathrm{Fe}_{3} \mathrm{O}_{4}$ coated with zirconium oxyhydrate in order to remove high concentration toxic substances i.e., As(III/V) from aqueous solutions. This magnetic nanoparticle contained high attractive toward arsenic because zirconium oxyhydrate and excellent magnetic separability in the high-intensity magnetic field as well as good repeated for many times. The major effects on the removal of $\mathrm{As}(\mathrm{III} / \mathrm{V})$, such as initial As(III/V) concentration, adsorption time, temperature, solution $\mathrm{pH}$, co-existing anions, deabsorption and removal efficiency were investigated. The results clearly showed that the maximum adsorption capacity of $\mathrm{Fe}_{3} \mathrm{O}_{4} @ \mathrm{ZrO}(\mathrm{OH})_{2}$ to $\mathrm{As}(\mathrm{III})$ and $\mathrm{As}(\mathrm{V})$ calculated by Langmuir equation were 188.68 and $108.70 \mathrm{mg} / \mathrm{g}$, respectively. The adsorption time effect followed a pseudo-second-order rate equation, can get contact time to As(III/V) of $20 \mathrm{~min}$ to reach equilibrium. The enthalpy change $\left(\Delta \mathrm{H}^{\circ}\right)$ and entropy change $\left(\Delta \mathrm{S}^{\circ}\right)$ of $\mathrm{As}(\mathrm{III})$ were $17.38,61.43 \mathrm{~J} / \mathrm{mol} / \mathrm{K}$, which indicates the spontaneous nature of the As(III) adsorption process. The adsorption capacity of As(III) was increased from solution $\mathrm{pH}$ were 2-6 and decreased when pH were 9-12, while $\mathrm{As}(\mathrm{V})$ was always decreased along with the increase of solution $\mathrm{pH}$. Interference ions have more effect $\mathrm{As}(\mathrm{III})$ than $\mathrm{As}(\mathrm{V})$. This magnetic nanoparticle could use more than four times after it was desorbed by $\mathrm{NaOH}$. Besides, after using $\mathrm{Fe}_{3} \mathrm{O}_{4} @ \mathrm{ZrO}(\mathrm{OH})_{2}$ as adsorbent to deal with an initial concentration of $10 \mathrm{mg} / \mathrm{L}$ of $\mathrm{As}(\mathrm{III})$ and $1 \mathrm{mg} / \mathrm{L}$ of As(V) solution, surplus concentration of arsenic less than $10 \mathrm{ppb}$. It is concluded that the magnetic nanoparticle $\mathrm{Fe}_{3} \mathrm{O}_{4} @ \mathrm{ZrO}(\mathrm{OH})_{2}$ can be considered as a good settlement performance, high arsenic uptake capability and fine utilization make it potentially excellent and attractive material for arsenic removal in future.

Key Words: Arsenate, Arsenite, Adsorption, $\mathrm{Fe}_{3} \mathrm{O}_{4} @ \mathrm{ZrO}(\mathrm{OH})_{2}$.
\end{abstract}

\section{INTRODUCTION}

Arsenic is one of the toxic and carcinogenic substance in the drinking water is presently of a worldwide concern. The toxicity of arsenic to humans is well documented, which leads to some organs canceration including skin, lung, liver, kidney and bladder cancers ${ }^{1,2}$. Arsenic pollution due to natural factors and anthropogenic activities has been reported in a large amount of regions, especially in Asian countries, such us China, New Zealand, Japan and India ${ }^{3}$. In view of this, the World Health Organization (WHO) has set a maximum permissible concentration for arsenic in drinking water at $10 \mu \mathrm{g} / \mathrm{L}$ in $1993^{4,5}$. Consequently, removal of arsenic form drinking water is an imperative work of people's livelihood and our world.

Several effective technologies have been employed for removal of both As(III) and As(V) species in aqueous solution over the last few decades, including precipitation ${ }^{6,7}$, ion-exchange ${ }^{8}$, electrochemical measurement ${ }^{9}$, biotechno$\log y^{10}$, membrane filtration ${ }^{11}$ and adsorption ${ }^{12-14}$. Nevertheless, the difficulties to eliminate impurities of coagulation technology, high cost of resins and membrane, long period of the biotechnology are restricting their development. In order to develop such remediation technologies, adsorption is regarded as a potential method for its innovative attraction and economy. One of the standards for the selection of adsorbent mainly depends on its economic benefit and adsorption capacity. In recent years, a wide range of reasonable price sorbent materials such as zero-valent iron ${ }^{15}$, iron-containing compounds ${ }^{16,17}$, aluminum salt ${ }^{18}$, thulium, clay ${ }^{19}$, modified matter ${ }^{20}$, combination substance ${ }^{21}$, active material ${ }^{22}$, have been tested for removing arsenic from drinking water. However, the low adsorption capacities and slow adsorption speed of those materials are insufficient for wide application. As a novel adsorption material, nanoparticle ${ }^{23}$ are applied broadly owing to its outstanding adsorption capacity. Whereas its high cost, low reuse times and low recovery efficiency have limited its application in drinking water, particularly in the developing world. In order to overcome these drawbacks of the adsorbents, 
we picked the magnetic nanoparticle $\mathrm{Fe}_{3} \mathrm{O}_{4} @ \mathrm{ZrO}(\mathrm{OH})_{2}$ prepared in $\mathrm{Fe}_{3} \mathrm{O}_{4}$ coated with zirconium oxyhydrate because of transition metal zirconium own natural and excellent adsorption ability for arsenic solution and nanoparticles of $\mathrm{Fe}_{3} \mathrm{O}_{4}$ owing its high surface area and good magnetic separability.

In this present work, on the basis of chemical coprecipitation method we smoothly used zirconium oxyhydrate embedded with $\mathrm{Fe}_{3} \mathrm{O}_{4}$ nanoparticle synthesized magnetic nanoparticles as $\mathrm{Fe}_{3} \mathrm{O}_{4} @ \mathrm{ZrO}(\mathrm{OH})_{2}$. It has high surface area for nanoparticles and excellent adsorption ability for hydrogen zirconium oxide attached to the $\mathrm{Fe}_{3} \mathrm{O}_{4}$ surface. Moreover, it possesses strong magnetic properties could easily achieve solid-liquid separation through an external magnetic field. To our surprise, these magnetic nanoparticles adsorbent can be reused more than four times after desorbtion. Furthermore we investigated the adsorption behaviour including adsorption isotherm, adsorption kinetics, solution $\mathrm{pH}$, co-existing anions, desorption and removal efficiency of $\mathrm{Fe}_{3} \mathrm{O}_{4} @ \mathrm{ZrO}(\mathrm{OH})_{2}$ to $\mathrm{As}(\mathrm{III})$ and $\mathrm{As}(\mathrm{V})$.

\section{EXPERIMENTAL}

All reagents used in the experiment were analytical reagent-grade except $\mathrm{HCl}(\mathrm{GR}) . \mathrm{FeCl}_{3} \cdot 6 \mathrm{H}_{2} \mathrm{O}, \mathrm{FeSO}_{4} \cdot 7 \mathrm{H}_{2} \mathrm{O}$ were purchased from Xilong Chemical Corporation (Shantou, China) $\mathrm{ZrOCl}_{2} \cdot 8 \mathrm{H}_{2} \mathrm{O}$ was bought from sinohparm chemical reagent Corporation (shanghai, China). $\mathrm{Na}_{2} \mathrm{HAsO}_{4} \cdot 12 \mathrm{H}_{2} \mathrm{O}$ (AR) and $\mathrm{NaAsO}_{2}$ (AR) obtained from Beijing Chemicals Corporation (Beijing, China). Ultrapure water used in all of the experiments was prepared by using Milli-Q water purification system (Xiamen China).

Preparation of magnetic nanoparticles $\mathrm{Fe}_{3} \mathrm{O}_{4} @ \mathrm{ZrO}(\mathrm{OH})_{2}$ : In order to prepare $\mathrm{Fe}_{3} \mathrm{O}_{4} @ \mathrm{ZrO}(\mathrm{OH})_{2}, \mathrm{Fe}_{3} \mathrm{O}_{4}$ was synthesized first of all. The $\mathrm{Fe}_{3} \mathrm{O}_{4}$ magnetic nanoparticles were prepared by the chemical coprecipitation method. The optimum experimental conditions for synthesizing $\mathrm{Fe}_{3} \mathrm{O}_{4}$ with appreciable modification as follows ${ }^{24}: 27.029 \mathrm{~g}$ of $\mathrm{FeCl}_{3} \cdot 6 \mathrm{H}_{2} \mathrm{O}$ and $13.901 \mathrm{~g}$ of $\mathrm{FeSO}_{4} \cdot 7 \mathrm{H}_{2} \mathrm{O}$ were mixed in three-neck flask in $50 \mathrm{~mL}$ ultrapure water, degassed with $\mathrm{N}_{2}$ 2-3 min. Then the mixed solution was stirred and heated $\left(85^{\circ} \mathrm{C}\right)$ in thermostat water bath cauldron. When the temperature of the mixture was stable, 2.0 $\mathrm{M} \mathrm{NaOH}$ was dropwise added to three-neck flask. Stop dropping when the solution into bright black. $\mathrm{Fe}_{3} \mathrm{O}_{4}$ nanoparticles were synthesized $2 \mathrm{~h}$ later. It was collected by a magnet and rinsed with deionized water for two times. Resuspended in $200 \mathrm{~mL}$ ultrapure water after washing.

$10 \mathrm{~mL} \mathrm{Fe}_{3} \mathrm{O}_{4}$ nanoparticles suspending liquid were mixed $0.01 \mathrm{M}, 100 \mathrm{~mL} \mathrm{ZrOCl}_{2} \cdot 8 \mathrm{H}_{2} \mathrm{O}$ in three-neck flask. Then 2.0 $\mathrm{M} \mathrm{NaOH}$ was dropwise added to three-neck flask. Stop dropping when the solution into bright black. After $2 \mathrm{~h}$, collected by a magnet and washed until the $\mathrm{pH}$ of the supernatant reached $c a$. 7. Resuspended in $200 \mathrm{~mL}$ ultrapure water preserve it by sealing it airtight after washing. This is $\mathrm{Fe}_{3} \mathrm{O}_{4} @ \mathrm{ZrO}(\mathrm{OH})_{2}$. During the whole process, temperature was maintained at $85^{\circ} \mathrm{C}$ and solution was stirred. Now the mass ratio of $\mathrm{Fe}_{3} \mathrm{O}_{4}-\mathrm{ZrOCl}_{2} \cdot 8 \mathrm{H}_{2} \mathrm{O}$ was 5:3. Similarly, displacement 20-30 $\mathrm{mL} \mathrm{Fe}_{3} \mathrm{O}_{4}$ nanoparticles suspending liquid. Synthesized $\mathrm{Fe}_{3} \mathrm{O}_{4} @ \mathrm{ZrO}(\mathrm{OH})_{2}$ in which the mass ratio of $\mathrm{Fe}_{3} \mathrm{O}_{4^{-}}$ $\mathrm{ZrOCl}_{2} \cdot 8 \mathrm{H}_{2} \mathrm{O}$ was $10: 3,15: 3$.
Preparation of arsenite $[\mathrm{As}(\mathrm{III})]$ and arsenate $[\mathrm{As}(\mathrm{V})]$ standard solutions: The As(III/V) stock solution (concentration of $1 \mathrm{~g} / \mathrm{L}$ ) was prepared from $0.1734 \mathrm{~g}$ of $\mathrm{NaAsO}_{2}$ and $0.537 \mathrm{~g}$ of $\mathrm{Na}_{2} \mathrm{HAsO}_{4} \cdot 12 \mathrm{H}_{2} \mathrm{O}$ dissolved in $\mathrm{H}_{2} \mathrm{SO}_{4}(1 \%)$ to volumetric flask $(100 \mathrm{~mL})$, respectively. Obtain every different concentration ready for the continuation use through dilution effect. The $\mathrm{pH}$ of the solutions was adjusted with $\mathrm{HCl}$ and $\mathrm{NaOH}$ to designated values in the range of 2-12.

Arsenic adsorption: Batch adsorption experiments were conducted by adding $20 \mathrm{~mL}$ aqueous solution in $100 \mathrm{~mL}$ conical flask. Solution $\mathrm{pH}$ was adjusted with $\mathrm{HCl}$ and $\mathrm{NaOH}$ to designated values. The $\mathrm{Fe}_{3} \mathrm{O}_{4} @ \mathrm{ZrO}(\mathrm{OH})_{2}$ suspensions were stirred and ultrasonic washing $10 \mathrm{~min}$. Then $1 \mathrm{~mL}$ of $\mathrm{Fe}_{3} \mathrm{O}_{4} @ \mathrm{ZrO}(\mathrm{OH})_{2}$ suspensions $(10 \mathrm{mg} / \mathrm{mL})$ was added into conical flask. The mixtures were shaken for $0.5 \mathrm{~h}$ in constant temperature oscillation box at $25^{\circ} \mathrm{C}$. The supernatant were collected use a strong magnet bar was placed on the bottom of the conical flask. Then the residual concentrations of arsenic were determined with an AFS-8220.

The isotherm tests were carried out with a series of initial arsenic concentrations reach to the equilibrium. The solution $\mathrm{pH}$ and temperature was controlled at $6-7$ and $25^{\circ} \mathrm{C}$, respectively. The kinetic experiments were conducted by the timedependent adsorption reactions. Different initial arsenic concentrations and different temperature were investigated. The tests of all kinds of anions and water adsorption indicate that various anions co-exist with arsenic effects the adsorption capacity of arsenic. The desorption tests were carried out using $\mathrm{NaOH}$ elution the $\mathrm{Fe}_{3} \mathrm{O}_{4} @ \mathrm{ZrO}(\mathrm{OH})_{2}$ were adsorbed in order to obtain the desorption times of $\mathrm{Fe}_{3} \mathrm{O}_{4} @ \mathrm{ZrO}(\mathrm{OH})_{2}$.

Analytic method: The atomic fluorescence spectrometry (AFS-8220) was used to determine the arsenic. This instrument was equipped with a boosted-discharge hollow cathode lamp, the separation of the gaseous arsines from the liquid stream was performed in a PS analytical type A gas-liquid separator, using argon as carrier gas. A hydrogen flow was also added to support the hydrogen-argon diffusion flame of the detector. The analog signal output was connected to a computer ${ }^{25}$.

\section{RESULTS AND DISCUSSION}

Adsorption isotherms: Langmuir and Freundlich isotherm models were used to analyze the experimental adsorption equilibrium date. It is presented by the following equation ${ }^{26}$ :

$$
\begin{aligned}
\frac{\mathrm{C}_{\mathrm{e}}}{\mathrm{q}_{\mathrm{e}}} & =\frac{\mathrm{C}_{\mathrm{e}}}{\mathrm{q}_{\mathrm{m}}}+\frac{1}{\mathrm{k}_{\mathrm{L}} \mathrm{q}_{\mathrm{m}}} \\
\log \mathrm{q}_{\mathrm{e}} & =\frac{1}{\mathrm{n}} \log \mathrm{C}_{\mathrm{e}}+\log \mathrm{k}_{\mathrm{F}}
\end{aligned}
$$

where $\mathrm{q}_{\mathrm{e}}(\mathrm{mg} / \mathrm{g})$ and $\mathrm{C}_{\mathrm{e}}(\mathrm{mg} / \mathrm{L})$ were the equilibrium adsorption capacity and the equilibrium adsorbate concentration, respectively; $\mathrm{K}_{\mathrm{L}}(\mathrm{L} / \mathrm{mg})$ and $\mathrm{q}_{\mathrm{m}}(\mathrm{mg} / \mathrm{g})$ are the Langmuir constants related to the energy of adsorption and maximum capacity, respectively; $\mathrm{K}_{\mathrm{F}}\left(\mathrm{mg}^{1-(1 / \mathrm{n})} \mathrm{L}^{1 / \mathrm{n}} / \mathrm{g}\right)$ and $1 / \mathrm{n}$ are the Freundlich constants related to the adsorption capacity and intensity, respectively.

The equilibrium data for $\mathrm{As}(\mathrm{III})$ and $\mathrm{As}(\mathrm{V})$ adsorption are shown in Fig. 1. The magnetic $\mathrm{Fe}_{3} \mathrm{O}_{4} @ \mathrm{ZrO}(\mathrm{OH})_{2}$ adsorbents possess high affinity to As(III) than As(V) (Fig. 1). With the decreasing mass ratio of $\mathrm{ZrOCl}_{2} \cdot 8 \mathrm{H}_{2} \mathrm{O}$, the amount 
of adsorbed As(III/V) decreased distinctly. So the conclusion can be concluded that the $\mathrm{ZrOCl}_{2} \cdot 8 \mathrm{H}_{2} \mathrm{O}$ layer thickness results in the adsorption capacity of the $\mathrm{Fe}_{3} \mathrm{O}_{4} @ \mathrm{ZrO}(\mathrm{OH})_{2}$.
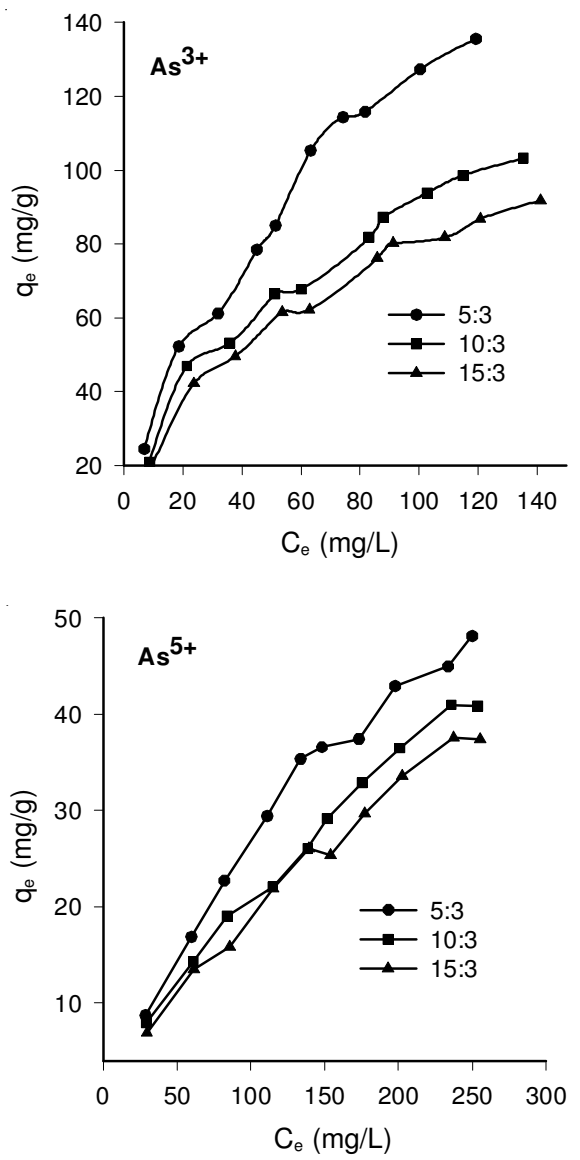

Fig. 1. Adsorption isotherms of $\mathrm{As}(\mathrm{III})$ and $\mathrm{As}(\mathrm{V})$ by $\mathrm{Fe}_{3} \mathrm{O}_{4} @ \mathrm{ZrO}(\mathrm{OH})_{2}$ with various mass ratio of $\mathrm{Fe}_{3} \mathrm{O}_{4}$ to $\mathrm{ZrOCl}_{2} \cdot 8 \mathrm{H}_{2} \mathrm{O}, \mathrm{pH}=7$

The results of fitting Langmuir and Freundlich equations to isotherm curves are presented in Fig. 2. Correlation coefficients were calculated for both isotherm models in Table- 1 .

Regression coefficients $\left(\mathrm{r}^{2}\right)$ for different conditions were larger than 0.91, demonstrating that both Langmuir and freundlich models were fit for representing the adsorption behaviour of $\mathrm{As}(\mathrm{III} / \mathrm{V})$ on the magnetic $\mathrm{Fe}_{3} \mathrm{O}_{4} @ \mathrm{ZrO}(\mathrm{OH})_{2}$. The maximum adsorption capacities $\left(\mathrm{q}_{\mathrm{m}}\right)$ of $\mathrm{As}(\mathrm{III})$ obtained for $\mathrm{Fe}_{3} \mathrm{O}_{4} @ \mathrm{ZrO}(\mathrm{OH})_{2}(5: 3)$ was $188.68 \mathrm{mg} / \mathrm{g}, \mathrm{Fe}_{3} \mathrm{O}_{4} @ \mathrm{ZrO}(\mathrm{OH})_{2}$ (10:3) for $140.85 \mathrm{mg} / \mathrm{g}$ and $\mathrm{Fe}_{3} \mathrm{O}_{4} @ \mathrm{ZrO}(\mathrm{OH})_{2}$ (15:3) for $123.46 \mathrm{mg} / \mathrm{g}$ at $25^{\circ} \mathrm{C}$. Compared with $\mathrm{As}(\mathrm{V})$ obtained for $\mathrm{Fe}_{3} \mathrm{O}_{4} @ \mathrm{ZrO}(\mathrm{OH})_{2}(5: 3)$ was $108.70 \mathrm{mg} / \mathrm{g}, \mathrm{Fe}_{3} \mathrm{O}_{4} @ \mathrm{ZrO}(\mathrm{OH})_{2}$
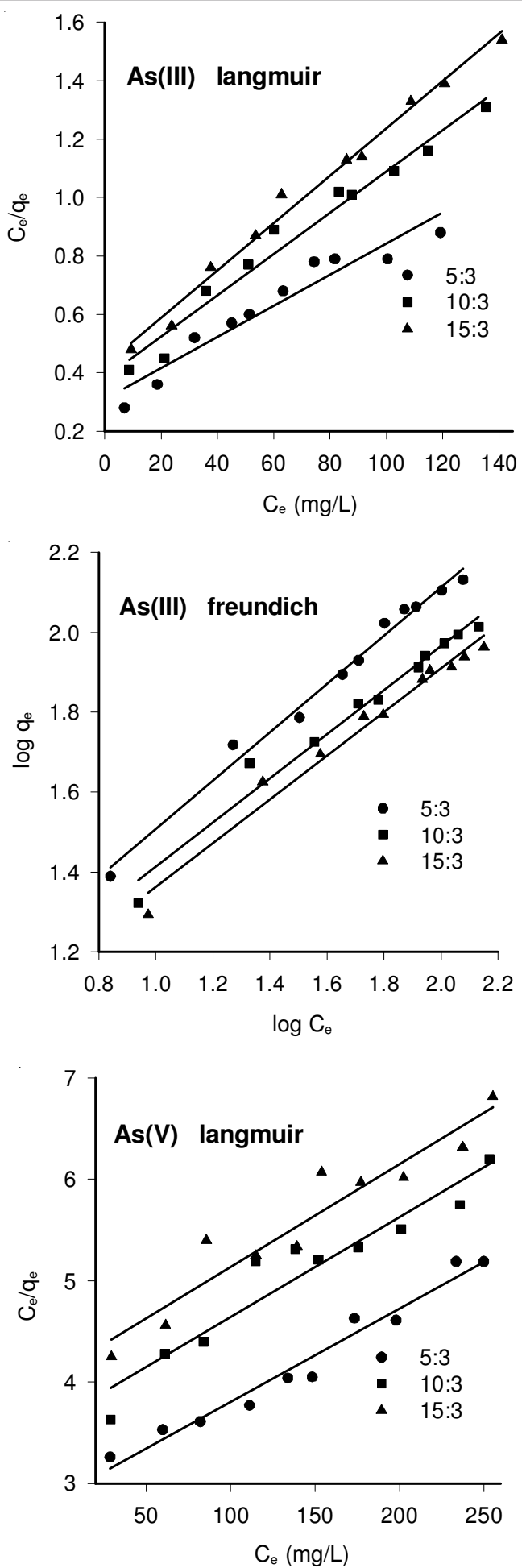

TABLE-1

LANGMUIR, FREUNDLICH ISOTHERMS PARAMETERS FOR As(III) AND As(V) ADSORPTION ONTO THE $\mathrm{Fe}_{3} \mathrm{O}_{4} @ \mathrm{ZrO}(\mathrm{OH})_{2}$ NANOPARTICLES

\begin{tabular}{|c|c|c|c|c|c|c|c|}
\hline \multirow{2}{*}{\multicolumn{2}{|c|}{ Parameter $\mathrm{Fe}_{3} \mathrm{O}_{4} @ \mathrm{ZrO}(\mathrm{OH})_{2}$}} & \multicolumn{3}{|c|}{ Langmuir isotherm model } & \multicolumn{3}{|c|}{ Freundich isotherm model } \\
\hline & & $\mathrm{q}_{\mathrm{m}}(\mathrm{mg} / \mathrm{g})$ & $\mathrm{K}_{\mathrm{L}}(\mathrm{L} / \mathrm{mg})$ & $\mathrm{r}^{2}$ & $\mathrm{~K}_{\mathrm{F}}\left(\mathrm{mg}^{1-(1 / \mathrm{n})} \mathrm{L}^{1 / \mathrm{n}} / \mathrm{g}\right)$ & $\mathrm{n}$ & $\mathrm{r}^{2}$ \\
\hline \multirow{3}{*}{$\mathrm{As}(\mathrm{III})$} & $10: 3$ & 188.68 & 0.01716 & 0.9285 & 8.0131 & 1.6540 & 0.9876 \\
\hline & $20: 3$ & 140.85 & 0.01851 & 0.9720 & 7.2344 & 1.8080 & 0.9735 \\
\hline & $30: 3$ & 123.46 & 0.01905 & 0.9887 & 6.5298 & 1.8262 & 0.9752 \\
\hline \multirow{3}{*}{ As $(V)$} & $10: 3$ & 108.70 & 0.003187 & 0.9661 & 0.6936 & 1.2825 & 0.9869 \\
\hline & $20: 3$ & 101.01 & 0.002710 & 0.9185 & 0.6051 & 1.3011 & 0.9965 \\
\hline & $30: 3$ & 98.04 & 0.002477 & 0.9111 & 0.4928 & 1.2639 & 0.9934 \\
\hline
\end{tabular}

$\mathrm{As}(\mathrm{III} / \mathrm{V})$ at $\mathrm{pH} 7$, adsorbent: $10 \mathrm{mg} / \mathrm{mL}$, temperature: $25^{\circ} \mathrm{C}$. 


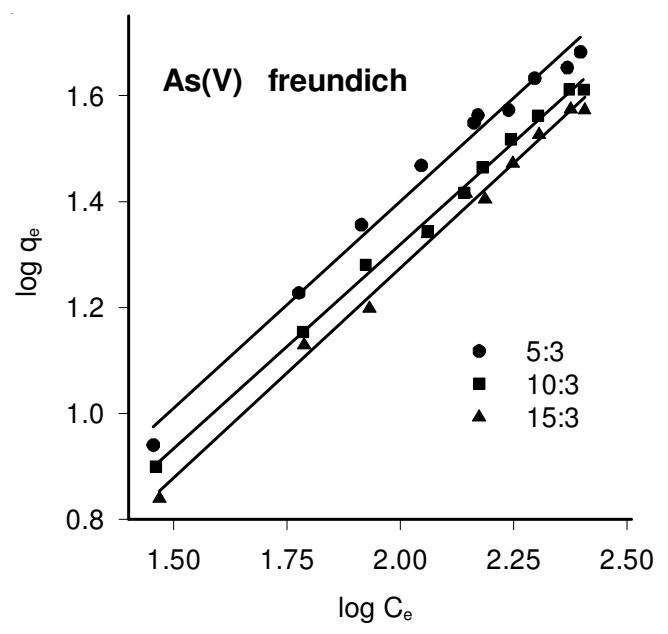

Fig. 2. Langmuir, Freundlich isotherms for As(III/V) adsorption on $\mathrm{Fe}_{3} \mathrm{O}_{4} @ \mathrm{ZrO}(\mathrm{OH})_{2}$ with various of mass ratio of $\mathrm{Fe}_{3} \mathrm{O}_{4}$ to $\mathrm{ZrOCl}_{2} \cdot 8 \mathrm{H}_{2} \mathrm{O}$

(10:3) for $101.01 \mathrm{mg} / \mathrm{g}$ and $\mathrm{Fe}_{3} \mathrm{O}_{4} @ \mathrm{ZrO}(\mathrm{OH})_{2}$ (15:3) for 98.04 $\mathrm{mg} / \mathrm{g}$ at $25^{\circ} \mathrm{C}$, which was lower than As(III). The Freundlich adsorption intensity parameters (n values) were higher As(III) than $\mathrm{As}(\mathrm{V})$ as one reason can account for the adsorption capacity of As(III) is stronger than As(V).

Adsorption kinetics study: Kinetic studies provide information about time required for the establishment of sorption equilibrium. Various models can represent the behaviour of a batch adsorption process. We use the pseudosecond-order kinetic model ${ }^{26}$ is presented as:

$$
\frac{\mathrm{t}}{\mathrm{q}_{\mathrm{t}}}=\frac{1}{\mathrm{k}_{2} \mathrm{q}_{\mathrm{e}}^{2}}+\frac{\mathrm{t}}{\mathrm{q}_{\mathrm{e}}}
$$

where $k_{2}$ is the rate constant of adsorption ( $\left.g / m g / m i n\right), q_{t}$ is the amount of arsenic adsorbed by adsorbent at any time ( $\mathrm{mg} /$ $\mathrm{g}), \mathrm{q}_{\mathrm{e}}$ is equilibrium adsorption capacity $(\mathrm{mg} / \mathrm{g}$ ) and the initial sorption rate, $\mathrm{h}_{0}(\mathrm{mg} / \mathrm{g} / \mathrm{min})$ can be defined as:

$$
\mathrm{h}_{0}=\mathrm{k}_{2} \mathrm{q}_{\mathrm{e}}^{2}(\mathrm{t} \rightarrow \mathrm{o})
$$

Both $\mathrm{k}_{2}$ and $\mathrm{h}_{0}$ could be determined experimentally by plotting of $\mathrm{t} / \mathrm{q}_{\mathrm{t}}$ versus $\mathrm{t}$.

The experiments about adsorption rate of $\mathrm{As}(\mathrm{III} / \mathrm{V})$ adsorption on the $\mathrm{Fe}_{3} \mathrm{O}_{4} @ \mathrm{ZrO}(\mathrm{OH})_{2}$ (10:3) nanoparticles surface were carried out by different initial As(III/V) concentration and various chemical reaction temperature. The samples were taken different periods of time and analyzed for their As(III/V) concentration, was shown in Figs. 3 and 4.
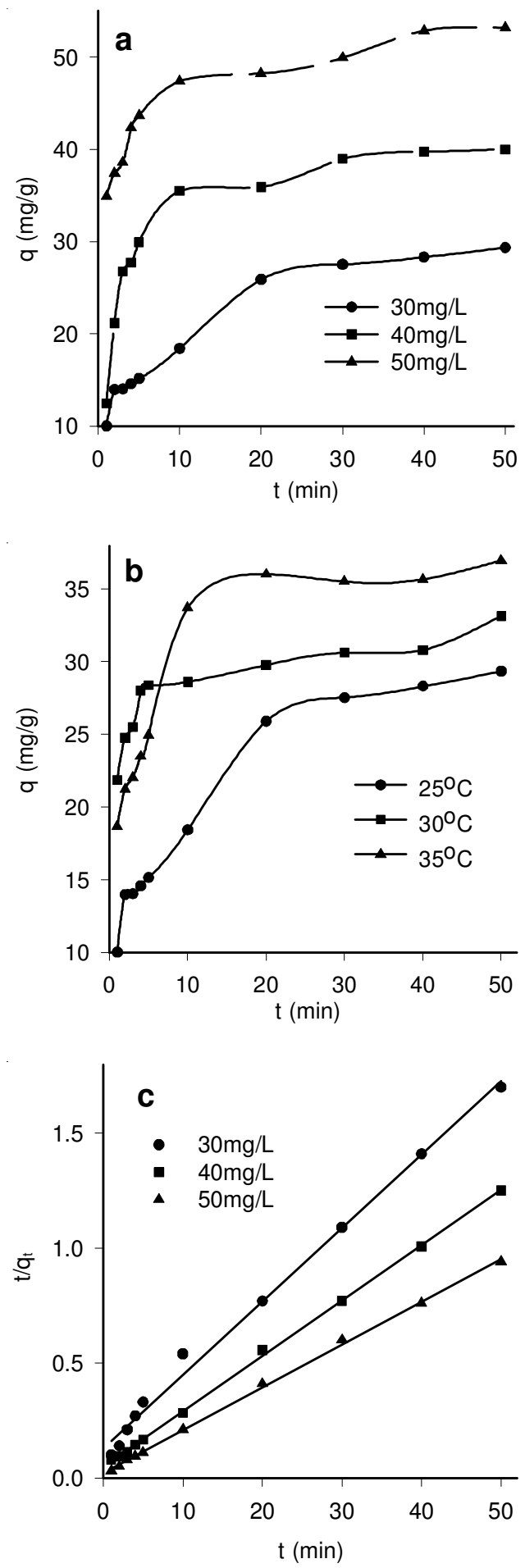

TABLE-2

PSEUDO-SECOND-ORDER KINETIC PARAMETERS OF As(III/V) ADSORPTION ONTO THE $\mathrm{Fe}_{3} \mathrm{O}_{4} @ \mathrm{ZrO}(\mathrm{OH})_{2}$ (10:3) NANOPARTICLES

\begin{tabular}{cllccccc}
\hline \multicolumn{2}{c}{$\mathrm{Fe}_{3} \mathrm{O}_{4} @ \mathrm{ZrO}(\mathrm{OH})_{2}$} & \multicolumn{3}{c}{ Different initial concentration ${ }^{\mathrm{a}}$} & \multicolumn{3}{c}{ Different temperature $^{\mathrm{b}}$} \\
\hline & Parameter & At $30 \mathrm{mg} / \mathrm{L}$ & $\mathrm{At} 40 \mathrm{mg} / \mathrm{L}$ & At $50 \mathrm{mg} / \mathrm{L}$ & At $25^{\circ} \mathrm{C}$ & At $30^{\circ} \mathrm{C}$ & At $35^{\circ} \mathrm{C}$ \\
$\mathrm{As}$ & $\mathrm{k}_{2}(\mathrm{~g} / \mathrm{mg} / \mathrm{min})$ & 0.007864 & 0.01188 & 0.01663 & 0.007864 & 0.03227 & 0.01447 \\
$(\mathrm{III})$ & $\mathrm{q}_{\mathrm{e}}(\mathrm{mg} / \mathrm{g})$ & 31.35 & 41.49 & 53.76 & 31.35 & 32.47 & 38.02 \\
& $\mathrm{~h}_{0}(\mathrm{mg} / \mathrm{g} / \mathrm{min})$ & 7.73 & 20.45 & 48.08 & 7.73 & 34.01 & 20.92 \\
& $\mathrm{r}^{2}$ & 0.9939 & 0.9994 & 0.9989 & 0.9939 & 0.9974 & 0.9988 \\
\hline & Parameter & At $55 \mathrm{mg} / \mathrm{L}$ & $\mathrm{At} 85 \mathrm{mg} / \mathrm{L}$ & $\mathrm{At} 115 \mathrm{mg} / \mathrm{L}$ & At $25^{\circ} \mathrm{C}$ & At $30^{\circ} \mathrm{C}$ & At $35^{\circ} \mathrm{C}$ \\
$\mathrm{As}$ & $\mathrm{k}_{2}(\mathrm{~g} / \mathrm{mg} / \mathrm{min})$ & 0.04134 & 0.01889 & 0.01568 & 0.01889 & 0.01621 & 0.01158 \\
$(\mathrm{~V})$ & $\mathrm{q}_{\mathrm{e}}(\mathrm{mg} / \mathrm{g})$ & 13.66 & 27.32 & 39.06 & 27.32 & 30.21 & 33.33 \\
& $\mathrm{~h}_{0}(\mathrm{mg} / \mathrm{g} / \mathrm{min})$ & 7.72 & 14.10 & 23.92 & 14.10 & 14.79 & 12.87 \\
& $\mathrm{r}^{2}$ & 0.9965 & 0.9985 & 0.9997 & 0.9985 & 0.9990 & 0.9970 \\
\hline
\end{tabular}

${ }^{\mathrm{a}} \mathrm{pH}$ 7, adsorbent: $10 \mathrm{mg} / \mathrm{mL}$, temperature: $25^{\circ} \mathrm{C} .{ }^{\mathrm{b}} \mathrm{pH}$ 7, adsorbent: $10 \mathrm{mg} / \mathrm{mL}$, initial As(III/V) concentration: (40/85) $\mathrm{mg} / \mathrm{L}$. 


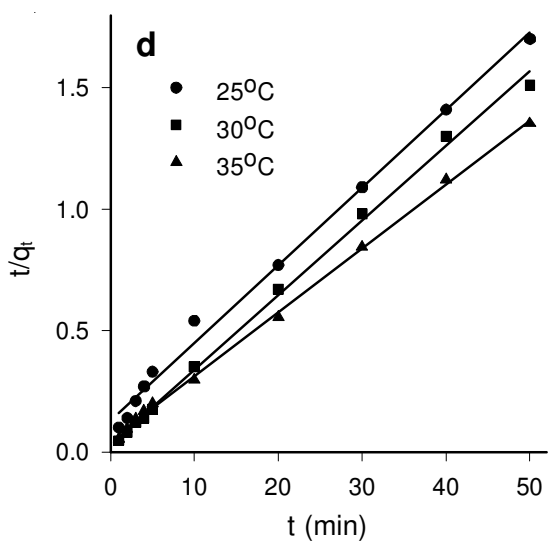

Fig. 3. Effects of reaction time on As(III) removal using adsorbent (a, c) linear fit of experimental data obtained using pseudo-second order kinetic model (b, d). $\mathrm{pH}=7$; adsorbent: $10 \mathrm{mg} / \mathrm{mL}$; temperature: 25 ${ }^{\circ} \mathrm{C}(\mathrm{a})$; initial As(III) concentration: $40 \mathrm{mg} / \mathrm{L}$ (b)
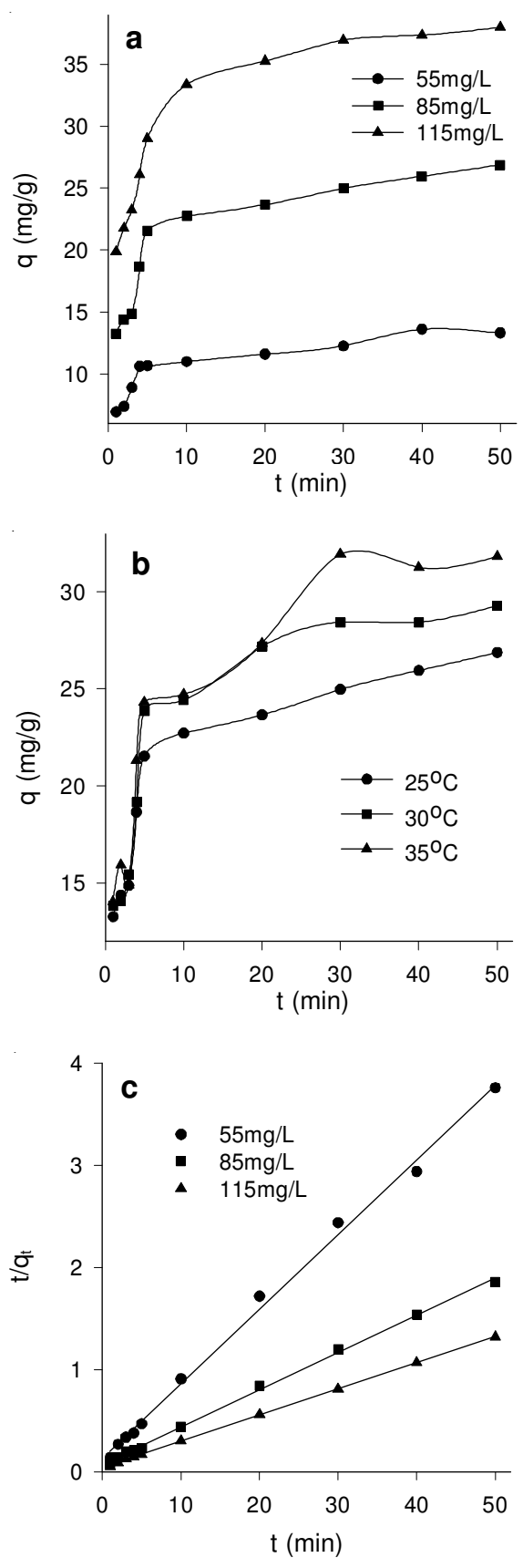

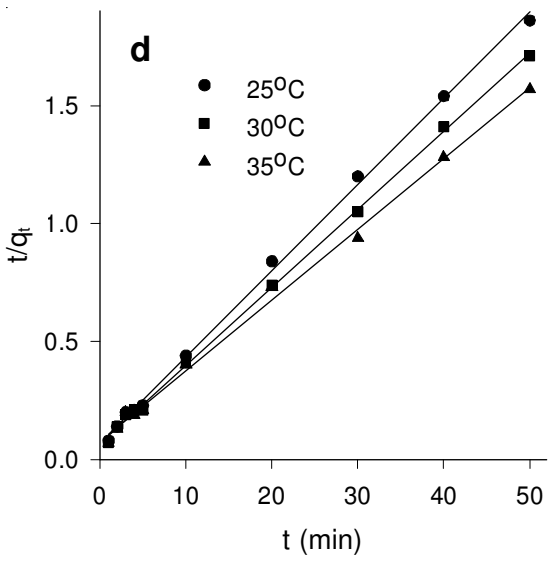

Fig. 4. Effects of reaction time on $\mathrm{As}(\mathrm{V})$ removal using adsorbent (a, c) linear fit of experimental data obtained using pseudo-second order kinetic model (b, d). $\mathrm{pH}=7$; adsorbent: $10 \mathrm{mg} / \mathrm{mL}$; temperature: $25^{\circ} \mathrm{C}$. (a) Initial As(V) concentration: $85 \mathrm{mg} / \mathrm{L}$ (b)

The As(III) removal reached equilibrium after of $20 \mathrm{~min}$ can be known from Figs. 3 and 4. However, As(V) could reach to equilibrium about $10 \mathrm{~min}$. Constant $\mathrm{k}_{2}$ and maximum adsorption capacity $\mathrm{q}_{\mathrm{e}}$ were calculated from the intercept and slope of this graph, respectively (Table-2).

The kinetics about magnetic $\mathrm{Fe}_{3} \mathrm{O}_{4} @ \mathrm{ZrO}(\mathrm{OH})_{2}$ nanomaterials adsorb As(III) and As(V) are expressed well by pseudo-second-order kinetic model $\left(r_{2}>0.99\right)$. The initial sorption rate $\mathrm{h}_{0}$ and equilibrium adsorption capacity $\mathrm{q}_{\mathrm{e}}$ values of As(III) were higher than those of As(V), indicating the faster adsorption rate of $\mathrm{As}(\mathrm{III})$ than that of $\mathrm{As}(\mathrm{V})$. For $\mathrm{As}(\mathrm{III} / \mathrm{V})$, $\mathrm{h}_{0}$ and $\mathrm{q}_{\mathrm{e}}$ values were higher along with the initial As(III/V) concentration higher.

Thermodynamic parameters: The thermodynamic parameters, the enthalpy change $\Delta \mathrm{H}^{\circ}$ and the entropy change $\Delta S^{\circ}$ were calculated from the slope and intercept of the plot of $\log \frac{\mathrm{q}_{\mathrm{e}}}{\mathrm{C}_{\mathrm{e}}}$ against $1 / \mathrm{T}$ according to the equation ${ }^{26}$ :

$$
\log \left(\frac{\mathrm{q}_{\mathrm{e}}}{\mathrm{C}_{\mathrm{e}}}\right)=\frac{\Delta \mathrm{S}^{\mathrm{o}}}{2.303 \mathrm{R}}-\left(\frac{\Delta \mathrm{H}^{\mathrm{o}}}{2.303 \mathrm{R}}\right) \frac{1}{\mathrm{~T}}
$$

where $\mathrm{q}_{\mathrm{e}}$ and $\mathrm{C}_{\mathrm{e}}$ are the adsorption equilibrium adsorption capacity and equilibrium concentration, respectively; $\Delta \mathrm{H}^{\circ}$ and $\Delta S^{\circ}$ are the change in enthalpy and entropy under standard states, respectively. $\mathrm{R}$ is the universal gas constant and $\mathrm{T}$ is the Kelvin temperature.

As related to temperature effect, the thermodynamic parameters have been calculated for this adsorption system. The free energy change of adsorption $\Delta \mathrm{G}^{\mathrm{o}}$ is calculated by using the equation:

$$
\Delta \mathrm{G}^{\mathrm{o}}=\Delta \mathrm{H}^{\mathrm{o}}-\mathrm{T} \Delta \mathrm{S}^{\mathrm{o}}
$$

where $\Delta \mathrm{G}^{\mathrm{o}}$ is the change in free energy.

The adsorption experiments were conducted in the temperature range of $25-35^{\circ} \mathrm{C}$ with $\mathrm{Fe}_{3} \mathrm{O}_{4} @ \mathrm{ZrO}(\mathrm{OH})_{2}$ concentration of $10 \mathrm{mg} / \mathrm{mL}$ and initial $\mathrm{As}(\mathrm{III})$ and $\mathrm{As}(\mathrm{V})$ concentration of $30 \mathrm{mg} / \mathrm{L}$ and $80 \mathrm{mg} / \mathrm{L}$ at initial $\mathrm{pH} 5.0$.

$\Delta \mathrm{H}^{\mathrm{o}}, \Delta \mathrm{G}^{\mathrm{o}}$ and Correlation $\mathrm{r}_{2}$ were obtained by plotting a graph between $\log \frac{q_{e}}{C_{e}}$ and $1 / T$ as shown in Fig. 5. For 


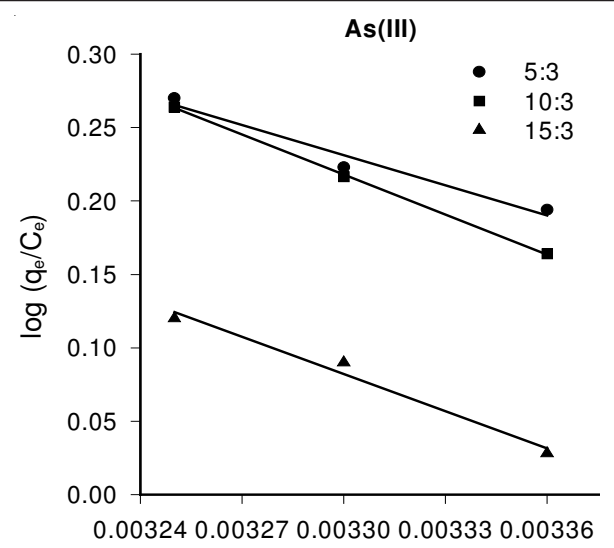

$1 / \mathrm{T}$

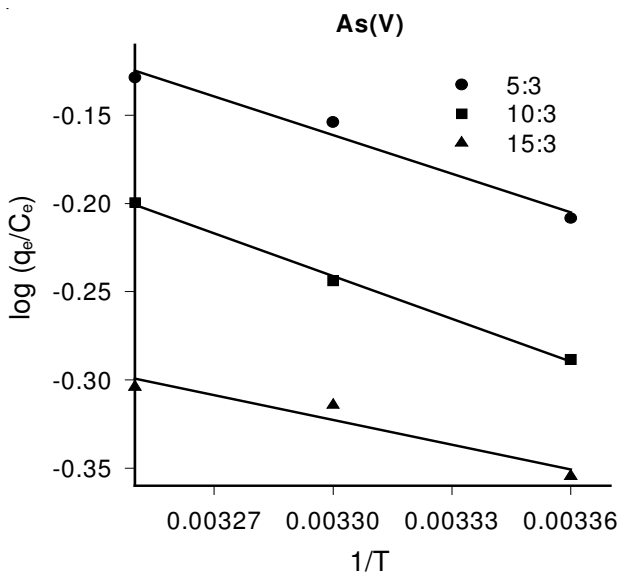

Fig. 5. Thermodynamics equation curve of $\mathrm{As}(\mathrm{III})$ and $\mathrm{As}(\mathrm{V}) . \mathrm{pH}=7$; adsorbent:10 mg/mL; initial As(III/V) concentration:(30/80) mg/L

example, the calculated value of $\Delta \mathrm{H}^{\mathrm{o}}$ for $\mathrm{Fe}_{3} \mathrm{O}_{4} @ \mathrm{ZrO}(\mathrm{OH})_{2}(10: 3)$ was $17.38 \mathrm{~kJ} / \mathrm{mol}$. The $\Delta \mathrm{S}^{\circ}$ was $61.43 \mathrm{~J} / \mathrm{mol} / \mathrm{K}$. Using the values of $\Delta \mathrm{H}^{\circ}$ and $\Delta \mathrm{S}^{\circ}$, the $\Delta \mathrm{G}^{\circ}$ values have been calculated by eqn. 6 and shown in Table-3. All of adsorbents of free energy As(III) changed less than zero indicated the adsorption of As(III) spontaneous process, which indicated the spontaneous nature of the As(III) adsorption process.

Effect of pH: The $\mathrm{pH}$ of aqueous solution usually plays an important role in deciding the amount of $\mathrm{As}(\mathrm{III} / \mathrm{V})$ adsorbed on $\mathrm{Fe}_{3} \mathrm{O}_{4} @ \mathrm{ZrO}(\mathrm{OH})_{2}$ nanoparticles ${ }^{27}$. Adsorption experiments were carried out at various aqueous phase $\mathrm{pH}$ (2-12) by keeping all other experimental conditions constant(reaction time, 0.5 $\mathrm{h}$; adsorbent concentration, $10 \mathrm{mg} / \mathrm{L}$; initial $\mathrm{As}(\mathrm{III})$ and $\mathrm{As}(\mathrm{V})$ concentration of $50 \mathrm{mg} / \mathrm{L}$ and $80 \mathrm{mg} / \mathrm{L}) .1 \mathrm{~mol} / \mathrm{L} \mathrm{HCl}$ and $\mathrm{NaOH}$ concentration were used for adjustment $\mathrm{pH}$. The effect of $\mathrm{pH}$ on the adsorbent process was shown in Fig. 6.

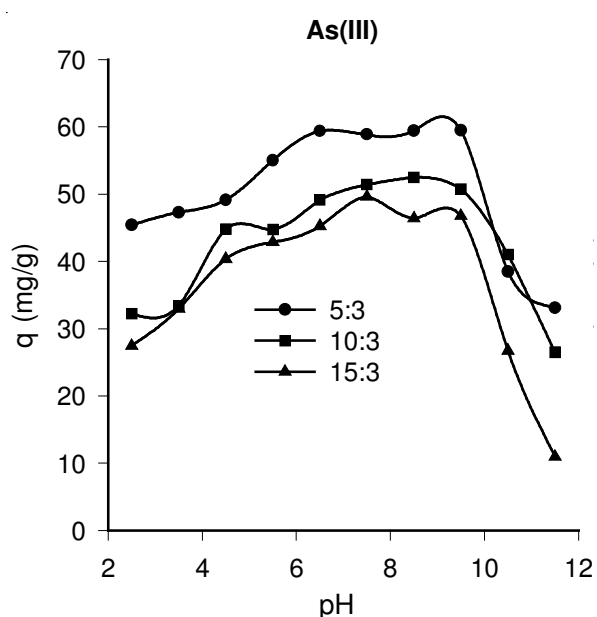

As(V)

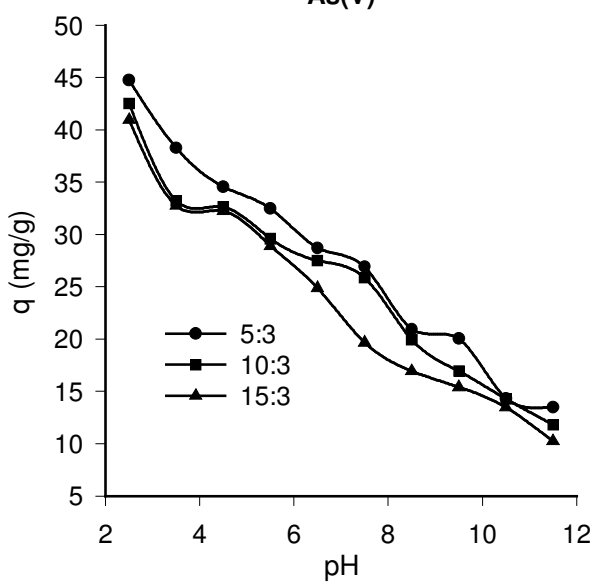

Fig. 6. Effect of $\mathrm{pH}$ on adsorption of $\mathrm{As}(\mathrm{III})$ and $\mathrm{As}(\mathrm{V})$ on various $\mathrm{Fe}_{3} \mathrm{O}_{4} @ \mathrm{ZrO}(\mathrm{OH})_{2}$ nanoparticles. Adsorbent: $1 \mathrm{mg} / \mathrm{mL}$; temperature: $25{ }^{\circ} \mathrm{C}$; initial As(III/V) concentration: (50/80) mg/L

It can be concluded that with the increase of solution $\mathrm{pH}$, adsorption capacity of $\mathrm{As}(\mathrm{III})$ on various $\mathrm{Fe}_{3} \mathrm{O}_{4} @ \mathrm{ZrO}(\mathrm{OH})_{2}$ nanoparticles present a certain appearance as parabola from Fig. 6. The adsorption quantity reached the biggest when $\mathrm{pH}$ (8-10). However, adsorption capacity of $\mathrm{As}(\mathrm{V})$ decreased with the increase of $\mathrm{pH}$ on various $\mathrm{Fe}_{3} \mathrm{O}_{4} @ \mathrm{ZrO}(\mathrm{OH})_{2}$ nanoparticles.

Effect of some interference ions over the adsorption capacity of As(III/V): Proverbially, the contaminated drinking and wastewater not only contain arsenic but also include several other co-existing ions, such as nitrate, sulfate and phosphate, which can compete with arsenic ion. When $\mathrm{Fe}_{3} \mathrm{O}_{4} @ \mathrm{ZrO}(\mathrm{OH})_{2}$ nanoparticles adsorb As(III/V). It is considered as the effect of competitive ions on the $\mathrm{Fe}_{3} \mathrm{O}_{4} @ \mathrm{ZrO}(\mathrm{OH})_{2}$.

TABLE-3

THERMODYNAMIC PARAMETER FOR ADSORPTION OF As(III/V) ONTO THE Fe $\mathrm{O}_{4} @ \mathrm{ZrO}(\mathrm{OH})_{2}(10: 3)$ NANOPARTICLES

\begin{tabular}{|c|c|c|c|c|c|c|c|}
\hline \multirow{2}{*}{\multicolumn{2}{|c|}{ Adsorbent $\mathrm{Fe}_{3} \mathrm{O}_{4} @ \mathrm{ZrO}(\mathrm{OH})_{2}$}} & \multirow{2}{*}{$\Delta \mathrm{H}^{\mathrm{o}}\left(\mathrm{kJ} \mathrm{mol}^{-1}\right)$} & \multirow{2}{*}{$\Delta \mathrm{S}^{\mathbf{o}}\left(\mathrm{J} \mathrm{mol}^{-1} \mathrm{~K}^{-1}\right)$} & \multirow{2}{*}{$r^{2}$} & \multicolumn{3}{|c|}{$\Delta \mathrm{G}^{\mathrm{o}}\left(\mathrm{kJ} \mathrm{mol}^{-1}\right)$} \\
\hline & & & & & At $25^{\circ} \mathrm{C}$ & At $30^{\circ} \mathrm{C}$ & At $35^{\circ} \mathrm{C}$ \\
\hline \multirow{3}{*}{ As(III) } & $10: 3$ & 13.09 & 47.63 & 0.9649 & -1.104 & -1.342 & -1.580 \\
\hline & $20: 3$ & 17.38 & 61.43 & 0.9995 & -0.9261 & -1.233 & -1.540 \\
\hline & $30: 3$ & 16.13 & 54.80 & 0.9786 & -0.2004 & -0.4744 & -0.7484 \\
\hline \multirow{3}{*}{$\mathrm{As}(\mathrm{V})$} & $10: 3$ & 13.98 & 43.06 & 0.9756 & 1.1481 & 0.9328 & 0.7175 \\
\hline & $20: 3$ & 15.44 & 46.35 & 0.9975 & 1.6277 & 1.396 & 1.164 \\
\hline & $30: 3$ & 8.95 & 23.41 & 0.9248 & 1.9738 & 1.857 & 1.740 \\
\hline
\end{tabular}

pH 7; adsorbent: $10 \mathrm{mg} / \mathrm{mL}$; initial As(III/V) concentration: (30/80) mg/L. 
Adsorption experiments were carried out by adding 100 $\mathrm{mg} / \mathrm{L}$ of $\mathrm{Cl}^{-}, \mathrm{NO}^{3-}, \mathrm{SO}_{4}{ }^{2-}, \mathrm{PO}_{4}{ }^{3-}$ and tap water, ground water, ganjiang water and ultrapure water preparation for $30 \mathrm{mg} / \mathrm{L}$ of As(III) and $80 \mathrm{mg} / \mathrm{L}$ of $\mathrm{As}(\mathrm{V})$ solution $20 \mathrm{~mL}$ throw $2 \mathrm{~mL}$ $\mathrm{Fe}_{3} \mathrm{O}_{4} @ \mathrm{ZrO}(\mathrm{OH})_{2}(10: 3)$. Fig. 8 shows the effect of various co-existing ions and different water environment on $\mathrm{As}(\mathrm{III} / \mathrm{V})$ adsorption by $\mathrm{Fe}_{3} \mathrm{O}_{4} @ \mathrm{ZrO}(\mathrm{OH})_{2}(10: 3)$.

As can be seen in Fig. 7, most of anion adsorbing capacity of As(III) is less than no ion (ultrapure water) except Ganjiang River. And for $\mathrm{As}(\mathrm{V})$, all of the anion adsorbing capacity is more than no ion. Interference ions effect more As(III) than $\mathrm{As}(\mathrm{V})$ in spite of the impact of adsorbing capacity is not significant.
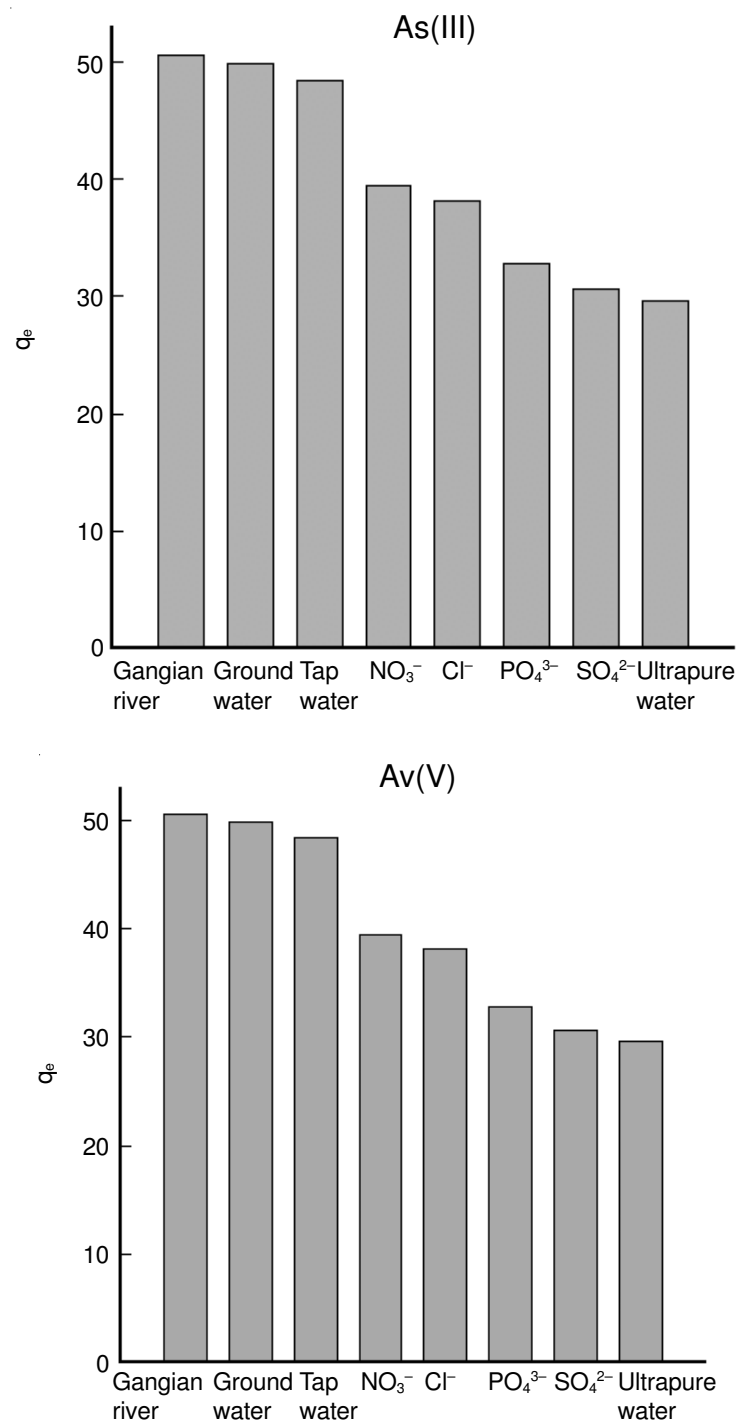

Fig. 7. Effect of different interference ion on the adsorption of As(III/V) by adsorbent. $\mathrm{pH}=7$; adsorbent: $1 \mathrm{mg} / \mathrm{mL}$; temperature: $25^{\circ} \mathrm{C}$; initial As(III/V) concentration: (30/80) mg/L

Desorption study: The sorbents has to be amenable to efficient regeneration and reuse. It is important to research the feasibility of $\mathrm{Fe}_{3} \mathrm{O}_{4} @ \mathrm{ZrO}(\mathrm{OH})_{2}$ magnetic nanomaterials to be regenerated after adsorption of arsenic. In high $\mathrm{pH}$, the surface hydroxyl groups got deprotonated and negatively charged, resulting in efficiently desorption of negatively charged arsenic species $^{28}$. Desorption study was carried out with
$\mathrm{Fe}_{3} \mathrm{O}_{4} @ \mathrm{ZrO}(\mathrm{OH})_{2}(10: 3)$ adsorbents conduct $50 \mathrm{mg} / \mathrm{L}$ of $\mathrm{As}(\mathrm{III} / \mathrm{V})$. Put the saturated adsorbent immerse in $2 \mathrm{M} \mathrm{NaOH}$ solution at constant temperature oscillation box $20 \mathrm{~min}$ with ultrasonic cleaning $10 \mathrm{~min}$ for twice, respectively. Then use deionized water to clean the adsorbent until the $\mathrm{pH}$ of the supernatant reached $\mathrm{ca}$. 7. Fig. 8 showed the adsorption capacity about $\mathrm{Fe}_{3} \mathrm{O}_{4} @ \mathrm{ZrO}(\mathrm{OH})_{2}(10: 3)$ adsorbents for As(III/ $\mathrm{V})$ were hardly any change after desorption of arsenic four times. So these magnetic nanomaterials would facilitate reuse.

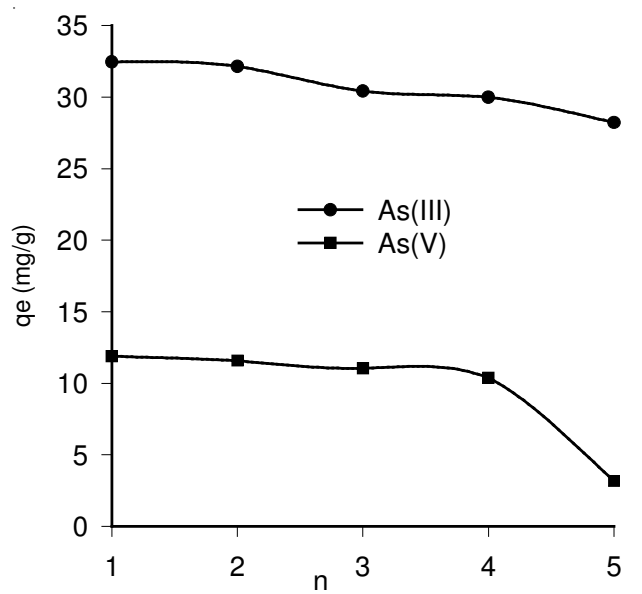

Fig. 8. Adsorption capacity of original and the regenerate adsorbent. $\mathrm{pH}=$ 7; adsorbent: $1 \mathrm{mg} / \mathrm{mL}$; temperature: $25^{\circ} \mathrm{C}$; initial $\mathrm{As}(\mathrm{III} / \mathrm{V})$ concentration: $50 \mathrm{mg} / \mathrm{L}$

Removal efficiency of As(III/V) solution: All of the sorbents are used for removal of As(III) and As(V) from solution so does $\mathrm{Fe}_{3} \mathrm{O}_{4} @ \mathrm{ZrO}(\mathrm{OH})_{2}$. It is necessary to research the removal efficiency of $\mathrm{As}(\mathrm{III} / \mathrm{V})$ solution by $\mathrm{Fe}_{3} \mathrm{O}_{4} @ \mathrm{ZrO}(\mathrm{OH})_{2}$. The experiment was carried out with $10 \mathrm{mg} / \mathrm{L}$ of $\mathrm{As}(\mathrm{III})$ and 1 $\mathrm{mg} / \mathrm{L}$ of $\mathrm{As}(\mathrm{V})$ solution on $\mathrm{Fe}_{3} \mathrm{O}_{4} @ \mathrm{ZrO}(\mathrm{OH})_{2}(10: 3)$ adsorbents which mass more and more. The As(III/V) concentration of solution were reduced less than $10 \mathrm{ppb}$. Removal efficiency exceeds $99.9 \%$ (Fig. 9).

Adsorption behaviour and possible mechanism: $\mathrm{ZrO}$ $(\mathrm{OH})_{2}$ is usually considered as the base for gel polymer formations of zirconium oxyhydrate ${ }^{29}$. The constitutional formula of arsenous acid [As(III)] and arsenic acid [As(V)] was also provided (Fig. 10). The zirconium atom appears two hydroxyl groups and one oxygroup. The arsenous acid atom links three hydroxyl groups and the arsenic acid atom connects two hydroxyl groups and one oxygroup.

The probable response equations ${ }^{30,31}$, which could describe the adsorption mechanism of $\mathrm{As}(\mathrm{III})$ and $\mathrm{As}(\mathrm{V})$, were adsorbed by $\mathrm{Fe}_{3} \mathrm{O}_{4} @ \mathrm{ZrO}(\mathrm{OH})$.

$$
\begin{aligned}
& \equiv \mathrm{ZrOH}+\mathrm{H}_{2} \mathrm{AsO}_{4}{ }^{-} \rightarrow \equiv \mathrm{ZrOAsO}_{4}^{2-}+\mathrm{H}^{+} \\
& \equiv \mathrm{ZrOH}+\mathrm{H}_{2} \mathrm{AsO}_{3}{ }^{-} \rightarrow \equiv \mathrm{ZrOAsO}_{3}^{2-}+\mathrm{H}^{+}
\end{aligned}
$$

Both arsenate and arsenite would adsorb to $\mathrm{Fe}_{3} \mathrm{O}_{4} @ \mathrm{ZrO}$ $(\mathrm{OH})_{2}$ by a ligand exchange reaction. That is - $\mathrm{OH}$ from zirconium oxyhydrate and $-\mathrm{H}_{2} \mathrm{AsO}_{4}{ }^{-} /-\mathrm{H}_{2} \mathrm{AsO}_{3}{ }^{-}$from $\mathrm{As}(\mathrm{V} / \mathrm{III})$ by ligand exchange reaction.

The former phenomenon can be easily explained. The three-dimensional space structure of $\mathrm{As}(\mathrm{III})$ and $\mathrm{As}(\mathrm{V})$ are 

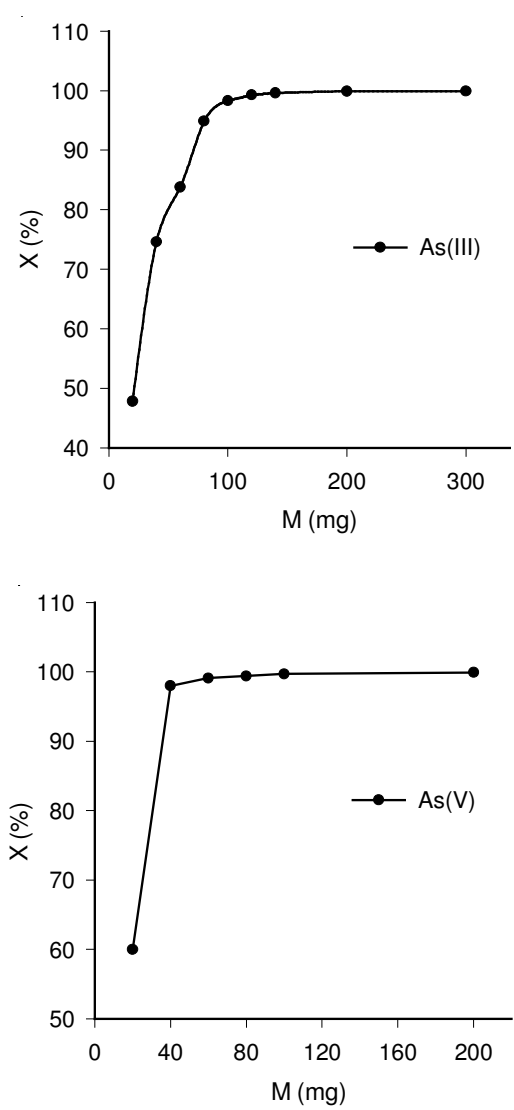

Fig. 9. Effects of adsorbent dosage on $\mathrm{As}(\mathrm{III} / \mathrm{V})$ removal using adsorbent. $\mathrm{pH}=7$; adsorbent: $1 \mathrm{mg} / \mathrm{mL}$; temperature: $25^{\circ} \mathrm{C}$; initial $\mathrm{As}(\mathrm{III} / \mathrm{V})$ concentration: $(10 / 1) \mathrm{mg} / \mathrm{L}$<smiles>O[As](O)O</smiles>

arsenous acid<smiles>O=[W](O)(O)O</smiles>

arsenic acid

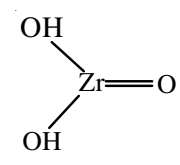

zirconium oxyhydrate
Fig. 10. Structure of the arsenous acid, arsenic acid and zirconium oxyhydrate

plane triangle and tetrahedron, respectively. It is well known that the little steric hinderance will make adsorption easier. However, the steric hinderance of tetrahedron is larger than plane triangle. So the magnetic $\mathrm{Fe}_{3} \mathrm{O}_{4} @ \mathrm{ZrO}(\mathrm{OH})_{2}$ adsorbents possess high adsorption capacity of As(III) than As(V). Meanwhile, why $\mathrm{As}(\mathrm{V})$ can reach to adsorption equilibrium faster than As(III) also may be understood.

$\mathrm{As}(\mathrm{III})$ and $\mathrm{As}(\mathrm{V})$ in different $\mathrm{pH}$ waters have their different forms. The monovalent anionic species of arsenate $\left(\mathrm{H}_{2} \mathrm{AsO}_{4}^{-}\right)$is predominant at $\mathrm{pH} 2-6$, while that of arsenite $\left(\mathrm{H}_{2} \mathrm{AsO}_{3}{ }^{-}\right)$range from $9-12^{32}$.

According to the eqns. 7 and 8 , an oxyhydrate with a negative charge in the zirconium oxyhydrate react with $\mathrm{H}_{2} \mathrm{AsO}_{4}{ }^{-}$and $\mathrm{H}_{2} \mathrm{AsO}_{3}{ }^{-}$in proportion of $1: 1$, while other forms of the arsenate or the arsenite is larger than $\mathrm{H}_{2} \mathrm{AsO}_{4}{ }^{-}$or $\mathrm{H}_{2} \mathrm{AsO}_{3}{ }^{-}$. So the same amount of oxyhydrate easier reacts with monovalent anions more than multivalent anions.

We can explain why the optimal $\mathrm{pH}$ ranged from 2-6 for $\mathrm{H}_{2} \mathrm{AsO}_{4}^{-}$while 9-12 for $\mathrm{H}_{2} \mathrm{AsO}_{3}^{-}$. But at high $\mathrm{pH}$, existing desorption effect adsorption capacity about As(III).
Characterization of $\mathrm{Fe}_{3} \mathrm{O}_{4} @ \mathrm{ZrO}(\mathrm{OH})_{2}$ adsorbents: The TEM image (Fig. 11) of $\mathrm{Fe}_{3} \mathrm{O}_{4} @ \mathrm{ZrO}(\mathrm{OH})_{2}$ nanoparticles clearly reveals the spherical surface feature, which endows the same particle size. The diameter of the particles was in between 10-15 $\mathrm{nm}$.

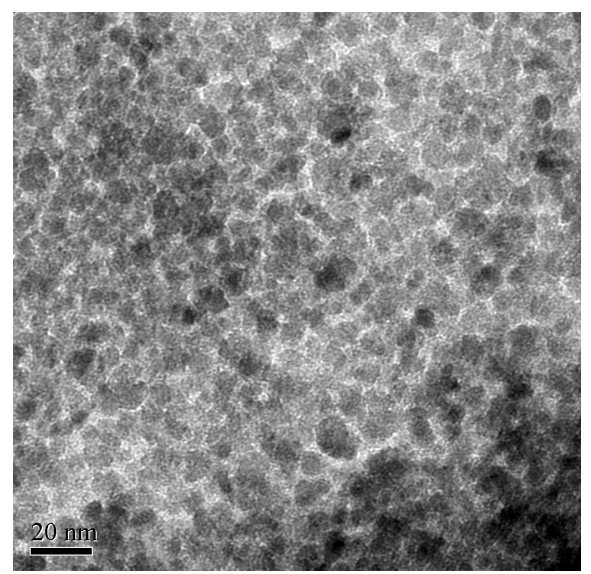

Fig. 11. TEM figure of the $\mathrm{Fe}_{3} \mathrm{O}_{4} @ \mathrm{ZrO}(\mathrm{OH})_{2}$

The XRD patterns of pure $\mathrm{ZrO}(\mathrm{OH})_{2}, \mathrm{Fe}_{3} \mathrm{O}_{4}$ and $\mathrm{Fe}_{3} \mathrm{O}_{4} @ \mathrm{ZrO}(\mathrm{OH})_{2}$ nanoparticles were described in Fig. 12. It clearly shown the $\mathrm{ZrO}(\mathrm{OH})_{2}$ has not appear, $\mathrm{Fe}_{3} \mathrm{O}_{4}$ has more apparent characteristic peak appeared. The $\mathrm{Fe}_{3} \mathrm{O}_{4} @ \mathrm{ZrO}(\mathrm{OH})_{2}$ has the similar characteristic peak with $\mathrm{Fe}_{3} \mathrm{O}_{4}$, but its strength decrease obviously. So it will be concluded the $\mathrm{Fe}_{3} \mathrm{O}_{4} @ \mathrm{ZrO}$ $(\mathrm{OH})_{2}$ retained some characteristics of $\mathrm{Fe}_{3} \mathrm{O}_{4}$, while it may contain other substances in its surface. The VSM magnetization curves of $\mathrm{Fe}_{3} \mathrm{O}_{4}$ nanoparticles, $\mathrm{Fe}_{3} \mathrm{O}_{4} @ \mathrm{ZrO}(\mathrm{OH})_{2}$ nanoparticles at room temperature was shown in Fig. 13. It can be known the magnetic nanoparticles exhibited typical magnetic behaviour, characterized with strong magnetic susceptibility, is a key factor for successful magnetic separation. Due to the weight contribution from the nonmagnetic $\mathrm{ZrO}(\mathrm{OH})_{2}$, $\mathrm{ZrO}(\mathrm{OH})_{2}$ amount increase results in the adsorbents magnetic strength decline.

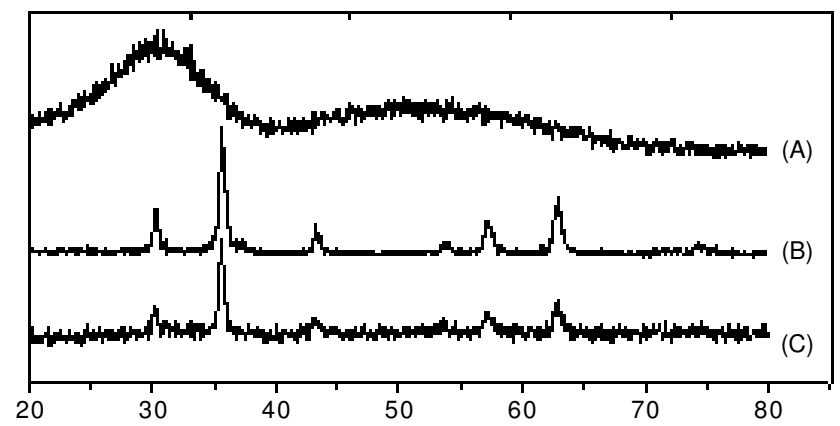

Fig. 12. XRD map comparison of the $\mathrm{ZrO}(\mathrm{OH})_{2}(\mathrm{~A}), \mathrm{Fe}_{3} \mathrm{O}_{4}(\mathrm{~B})$ and $\mathrm{Fe}_{3} \mathrm{O}_{4} @ \mathrm{ZrO}(\mathrm{OH})_{2}(\mathrm{C})$

\section{Conclusion}

This work investigated the synthesized method of magnetic nanoparticles $\mathrm{Fe}_{3} \mathrm{O}_{4} @ \mathrm{ZrO}(\mathrm{OH})_{2}$ and the adsorption property removal of $\mathrm{As}(\mathrm{III} / \mathrm{V})$ solution. The $\mathrm{Fe}_{3} \mathrm{O}_{4} @ \mathrm{ZrO}(\mathrm{OH})_{2}$ puts up these attractive merits: (a) High adsorption capacity toward As(III/V), especially to As(III) than others traditionnel 


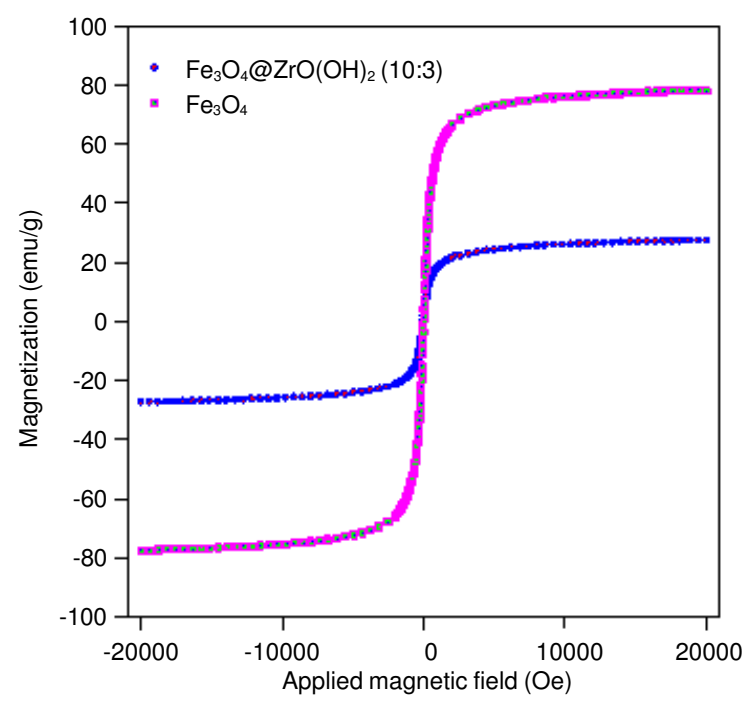

Fig. 13. VSM map comparison of the $\mathrm{Fe}_{3} \mathrm{O}_{4} @ \mathrm{ZrO}(\mathrm{OH})_{2}$ and $\mathrm{Fe}_{3} \mathrm{O}_{4}$

adsorbents owing to higher surface areas and zirconium possess natural affinity to arsenic. (b) Facile desorption, which can extend its adsorption times, meanwhile,its adsorption capacity not to decrease. (c) Rapid treatment effect, the $\mathrm{Fe}_{3} \mathrm{O}_{4} @ \mathrm{ZrO}(\mathrm{OH})_{2}$ can reduce time of reaction equilibrium concentration. In addition ferromagnetism can reduce time of solid-liquid separation by applied magnetic field. (d) Easy preparation, materials and implements of composing $\mathrm{Fe}_{3} \mathrm{O}_{4} @ \mathrm{ZrO}(\mathrm{OH})_{2}$ are business to buy. These merits have the very good application prospects.

\section{ACKNOWLEDGEMENTS}

This work was financially supported by a grant from the Scientific Research Fund of Jiangxi Provincial Education Department (GJJ10023).

\section{REFERENCES}

1. H.M. Anawar, J. Akai, K.M.G. Mostofa, S. Safiullah and S.M. Tareq, Environ. Int., 27, 597 (2002)

2. C.A. Martinson and K.J. Reddy, J. Colloid Interf. Sci., 336, 406 (2009).
3. W.J. Shao, X.M. Li, Q.L. Cao, F. Luo, J.M. Li and Y.Y. Du, Hydrometallurgy, 91, 138 (2008)

4. C.M. Steinmaus, Y. Yuan and A.H. Smith, Environ. Res., 99, 164 (2005).

5. M.H. Stanic, B. Kalajdzic, M. Kuleš and N. Velic, Desalination, 229, 1 (2008).

6. M.B. Baskan and A. Pala, J. Hazard. Mater., 166, 796 (2009).

7. B. Han, T. Runnells, J. Zimbron and R. Wickramasinghe, Desalination, 145, 293 (2002).

8. F.G.A. Vagliasindi and M.M. Benjamin, Water Sci. Technol., 38, 337 (1998).

9. S.B. Rasul, A.K.M. Munir, Z.A. Hossain, A.H. Khan, M. Alauddin and A. Hussam, Talanta, 58, 33 (2002).

10. P.K. Pandey, S. Choubey, Y. Verma, M. Pandey and K. Chandrashekhar, Bioresour. Technol., 100, 634 (2009).

11. D. Qu, J.Wang, D. Hou, Z. Luan, B. Fan and C. Zhao, J. Hazard. Mater., 163, 874 (2009).

12. A. Ramaswami, S. Tawachsupa and M. Isleyen, Water Res., 35, 4474 (2001).

13. O.S. Thirunavukkarasu, T. Viraraghavan and K.S. Subramanian, Water Air Soil Pollut., 142, 95 (2003).

14. A. Jain and R.H. Loeppert, J. Environ. Qual., 29, 1422 (2000).

15. H.W. Sun, L. Wang and R.H. Zhang, J. Hazard. Mater., 129, 297 (2006).

16. J.G. Parsons, M.L. Lopez, J.R. Peralta-Videa and J.L. Gardea-Torresdey, Microchem. J., 91, 100 (2009).

17. Y.F. Jia, L.Y. Xu, Z. Fang and G.P. Demopoulos, Environ. Sci. Technol., 40, 3248 (2006).

18. D.W. Oscarson, P.M. Huang, U.T. Hammer and W.K. Liaw, Water, Air, Soil Pollut., 20, 233 (1983).

19. Y.R. Li, J. Wang, Z.K. Luan and Z. Liang, J. Hazard. Mater., 177, 131 (2010).

20. N. Haque, G. Morrison, I. Cano-Aguilera and J.L. Gardea-Torresdey, Microchem. J., 88, 7 (2008).

21. V.K. Gupta, V.K. Saini and N. Jain, J. Colloid Interf. Sci., 288, 55 (2005).

22. H.S. Altundogan, S. Altundogan, F. Tumen and M. Bildik, Waste Manage., 22, 357 (2002)

23. K. Gupta and U.C. Ghosh, J. Hazard. Mater., 161, 884 (2009).

24. X.L. Zhao, J.M. Wang, F.C. Wu, T. Wang, Y.Q. Cai, Y.L. Shi and G.B. Jiang, J. Hazard. Mater., 173, 102 (2010).

25. F.E. Hadri, A.M. Rubio and M. de la Guardia, Talanta, 52, 653 (2000). 26. H. Uslu, Chem. Eng. J., 155, 320 (2009).

27. O. Sracek, P. Bhattacharya and G. Jacks, Appl. Geochem., 19, 169 (2004).

28. S. Sarkar, L.M. Blaney, A. Gupta, D. Ghosh and A.K. SenGupta, Environ. Sci. Technol., 42, 4268 (2008).

29. K.N. Ghimire, K. Inoue, H. Yamaguchi, K. Makino and T. Miyajima, Water Res., 37, 4945 (2003).

30. T. Balaji, T. Yokoyama and H. Matsunaga, Chemosphere, 59, 1169 (2005).

31. G.T. Schmidt, N. Vlasova, D. Zuzaan, M. Kersten and B. Daus, J. Colloid Interf. Sci., 317, 228 (2008).

32. A.J. Bard, R. Parsons and J. Jordan, Marcel Dekker, New York, p. 162 (1985). 